Expression of Concern

\title{
Expression of Concern: Takai, N. and Narahara, H. Epigenetic Therapy in Human Choriocarcinoma. Cancers 2010, 2, 1683-1688
}

\author{
Cancers Editorial Office \\ MDPI AG, Klybeckstrasse 64, CH-4057 Basel, Switzerland; cancers@mdpi.com; \\ Tel.: +41-61-683-77-34 \\ Academic Editor: Samuel C. Mok \\ Received: 6 April 2016; Accepted: 6 April 2016; Published: 7 April 2016
}

We wish to make readers aware that text in [1] has been taken from other publications by the same author. In particular, much of Section 1, the first part of Section 2 and the first sentence of Section 3 are copied verbatim from [2]. Table 1 and the second part of Section 2 are taken from [3]. The main novel contribution of [1] lies in Section 3. We regret that these issues were not picked up before publication and wish to apologize to readers of Cancers.

\section{References}

1. Takai, N.; Narahara, H. Epigenetic therapy in human choriocarcinoma. Cancers 2010, 2, 1683-1688. [CrossRef] [PubMed]

2. Takai, N.; Narahara, H. Histone deacetylase inhibitor therapy in epithelial ovarian cancer. J. Oncol. 2010, 2010, 458431. [CrossRef] [PubMed]

3. Takai, N.; Narahara, H. Preclinical studies of chemotherapy using histone deacetylase inhibitors in endometrial cancer. Obstet. Gynecol. Int. 2010, 2010, 923824. [CrossRef] [PubMed]

(C) 2016 by the author; licensee MDPI, Basel, Switzerland. This article is an open access article distributed under the terms and conditions of the Creative Commons Attribution (CC-BY) license (http://creativecommons.org/licenses/by/4.0/). 